\title{
Capital Market and Fiscal Policy Shocks in Nigeria
}

\author{
Ejem Chukwu Agwu 1, *, Ogbonna Udochukwu Godfrey ${ }^{2}$ \\ ${ }^{1}$ Department of Banking and Finance, Abia State University, Uturu, Nigeria \\ ${ }^{2}$ Department of Management Science, Rhema University, Aba, Nigeria
}

Email address:

ecjah71@yahoo.com (E. C. Agwu)

${ }^{*}$ Corresponding author

\section{To cite this article:}

Ejem Chukwu Agwu, Ogbonna Udochukwu Godfrey. Capital Market and Fiscal Policy Shocks in Nigeria. Journal of Finance and Accounting. Vol. 8, No. 3, 2020, pp. 125-135. doi: 10.11648/j.jfa.20200803.13

Received: May 7, 2020; Accepted: May 25, 2020; Published: June 3, 2020

\begin{abstract}
This study dissected fiscal policy from monetary policy to unravel its impact on Capital market performance in Nigeria and how capital market responds to fiscal policy measures. The empirical analysis came up with the following major findings; the Error Correction Model revealed that market Capitalization as a performance index in this study is autoregressive, implying that previous market capitalization can predict investors' perception of the market in the futures, also the model's results show that recurrent expenditure and Non-Oil Revenue have negative and significant relationship with capital market performance in Nigeria. And Domestic debt was found to have a positive and significant relationship with capital market performance, validating the Keynes's postulations reviewed in this study that government should adopt fiscal policy through deficit financing to put an end to further economic depression and related issues. Pairwise Granger Causality Test Results found bi-directional effect between domestic debt and market capitalization, implying that the duo drive each other or have feedback effect. Also VEC Granger Causality/Block Exogeneity Wald Test revealed that fiscal policy variables jointly cause capital market performance in the long run. The impulse responses revealed that shock market capitalization (own shock) exerted huge influence in the cause of variations on capital market performance followed by shocks from government expenditures. It is in light of the findings the researchers among others; advise the regulatory authorities in Nigeria that government revenues and expenditure be adequately orchestrated as main drivers to correct disequilibria in the Nigeria.
\end{abstract}

Keywords: Fiscal Policy, Market Capitalization, Impulse Responses, Nigeria

\section{Introduction}

The capital market as one of the environments of investment decisions is an avenue for the interactions among the surplus and deficit economic units of any economy. These interactions offers the surplus units to vent for the excess of their contemplated investment, while the deficit economic units made the deficiency or shortfalls by issuing financial claims on themselves. This is a veritable opportunity for the surplus economic units to procure income-yielding financial assets. In the words of Okafor [29], 'the process of interaction results in a simultaneous creation of financial assets and financial liabilities. It gives rise to constant changes on claims and counter claims to financial assets, changes which represent financial flows'. However, optimal financial flow is necessary for investment which depends majorly on the efficacy of policies and facilities made available by the regulatory and supervisory authorities of an economy. In Nigeria, fiscal policy is one of these policy measures employed to stabilize the economy. It is a restrictive or expansionary budgetary policy of the government aimed at manipulating the revenue sources, public expenditure and public debt for promoting economic conditions and actions consistent with business growth and economic stability.

Emphasizing on the relationship between fiscal policy and capital market, fiscal policy has been found to affect the performance of the capital market. Government fiscal policy measures, mostly expenditure can woo foreign and domestic investors into the market. Its instruments can affect the perception of investors negatively or positively. For instance whenever government introduces deficit budgeting as best-fit policy, investors is assumed to prefer a cut in public investment and a raise in taxes to reduced current expenditure. Alternatively, fiscal policy through deficit financing can induce an increase in interest rates with a 
corresponding reduction in the fund invested, thereby slowing growth in the capital market [32, 6, 3, 23].

The above insinuations have resulted to controversy on whether fiscal policy variables affect the performance of the capital market, hence came with these studies; several authors have put strong argument favouring substantial relationship between fiscal policy and capital market and a such can influence certain consequences on capital markets [36, 7, 9, 30, 27, 33, 1, 16, 19, 2]. Agnello et al. [4] singled out the direction of fiscal policy on capital market by illustrating the impact of fiscal variables on increasing of stock prices. That the capital market has a direct impact which is induced by increase in taxes associated to capital gained and fiscal revenue. These effects are felt by investors through indirect impact by increasing income, private consumption and the growth reducing interest rate. In the contrary, Tavares and Valkanov [36] were examining the taxes and government spending impact over stocks, government bonds, and corporate bonds and found that for any particular level of government expenditure, there seem to be no significant effect on stock and bond returns. Tavares and Valkanov [36] rather concluded that a rise in tax has a significant and negative effect which leads to reduced market returns. Simply put, fiscal policy is an impotent measure which has no effect on capital markets $[10,11]$.

However, in Nigeria despite several attempts made by regulatory and supervisory authorities to reposition the Nigeria capital market qua Nigeria Stock Exchange (NSE) with fiscalmonetary policy mix, it still fall below optimal performance or it has not yielded commensurate results. It is the desire of the researchers to dissect fiscal policy from monetary policy to empirically examine its impact on Capital market performance in Nigeria and how capital market responds to fiscal policy measures. Also, to add to the scarce empirical literature on the impact of fiscal policy and capital market in Nigeria. The remaining sections are organized as follows; 2-literature review, 3-Methodology, 4-Trend and Description of data, 5Results and 6-Conclusion and Recommendation.

\section{Literature Review}

Theoretically, fiscal policy is considered by most finance and economic scholars as one of the most important measures employed by governments to actualize economic stability. This was popularized immediately after the great depression of 1930s by John Maynard Keynes, a British economist. Keynes vehemently put up an argument that the deficiency hovering around demand and the resultant decline in production and employment could be eliminated through government intervention; what Adams Smith called invisible hand. According to Keynes, this can be achieved through government expenditure as a multiplier and accelerator for stimulating the economy. It is on that note that fiscal policy was brought into limelight focusing government's active participation in the regulation and manipulation of aggregate economic activities. Keynes believed that changes in saving and investment are responsible for changes in business activity and employment in an economy. Based on this premise, Keynes was bold to advocate government adoption of fiscal policy through deficit financing to put an end further economic depression and related issues $[25,8,13,35,31,2,20,26]$.

From the dimension of investor, it is necessary to an efficient capital market to ensure that an investor is involved in a fair game, whereas from economic point of view, the efficient capital market is the essential vehicle for optimal allocation of resources. The Efficient Market Hypothesis (EMH), also called Random Walk Theory, is the consideration that the equity value of a listed firm reflects all data regarding the business value. That means the market is efficient when stock prices instantaneously reflect supposedto-know or available information in the market. "Efficient market" was presented in 1965 by Eugene Fama. He suggested that stocks always trade at fair value. This makes it impossible for investors to buy undervalued stocks or to sell stocks at overestimated prices. A market is efficient if prices adjust rapidly and, on average, without bias to new info. Thus, there isn't a reason to believe that prices are excessively high or low [24, 17, 14, 18, 22, 34, 12].

Empirically, very few scholars examined the relationship between fiscal policy and capital market in Nigeria, unlike capital market and monetary policy studies that are awash in finance and economic literature. The researchers therefore make attempt to review the handy empirical studies on the subject matter.

Applying Ordinary Least Square (OLS), Error Correction Model (ECM), and VAR, Ogbulu, Torbira and Umezinwa [28] examined the relationship between government fiscal policy measures and stock prices in Nigeria. The result of the study showed negative and significant impact between government expenditure and stock prices, also found that government domestic debt and non-oil revenue impact negatively and significantly on stock prices. Again, that variations in stock prices was mainly attributed by own shock.

Eyo [15] employed ordinary least square of multiple regression technique to investigate the impact of the Nigerian fiscal policy on the performance of the Nigeria stock exchange. The fiscal policy tools used in the study are government revenue, government expenditure and government borrowing, whereas capital market performance was proxied by market capitalization. The outcome of the analysis revealed that government revenue and government expenditure significantly impact market capitalization. Again, government borrowing was found to have no impact on the performance of capital market.

With regression model, Anghelache, Jakova and Oanea [5] examined the relationship between fiscal policy and capital market performance in six European Union countries with data spanning from 2004 to 2015. After the analysis it was found that fiscal policy affects significantly the capital market returns in Czech Republic, Slovakia, Bulgaria and Poland, while insignificant relationship was found in Hungary and Romania.

\section{Methodology}

\subsection{Source of Data}

The data spanning from 1989 to 2018 were collected from 
Nigeria Stock Exchange (NSE) Annual Fact Books and Central Bank of Nigeria (CBN) Statistical Bulletin. For the variables; Market Capitalization (MKTCAP) proxy of Capital Market Performance, and Fiscal Policy Variables (Capital Expenditure (CEX), Recurrent Expenditure (REX), Non-Oil Revenue (NOR), Domestic Debt (DBT))

\subsection{Techniques}

In testing the stationarity of the variables, the Augmented
Dickey Fuller (ADF) unit root test is engaged; also to examine if long run relationship exists between the dependent and independent variables in this paper, Johansen Cointegration is used. Error Correction Model (ECM) is employed to testing the models and Vector Autoregressive (VAR) is employed to check the response to shocks of fiscal policy by capital market.

\subsection{Model Specification}

The functional form;

$$
\text { Capital Market Performance }=\mathrm{f}(\text { Fiscal Policy Variables })
$$

Market Capitalization $=\mathrm{f}($ Capital Expenditure, Recurrent Expenditure, Non-Oil Revenue Domestic Debt $)$

$$
\mathrm{MKTCAP}=\mathrm{f}(\mathrm{CEX}, \mathrm{REX}, \mathrm{NOR}, \mathrm{DBT})
$$

Then, the explicit form;

The reduced VAR model, incorporating Market Capitalization (MKTCAP), Capital Expenditure (CEX), Recurrent Expenditure (REX), Non-Oil Revenue (NOR), Domestic Debt (DBT) is shown below;

$$
\begin{gathered}
\text { MKTCAP }_{\mathrm{t}}=\alpha_{01}+\alpha_{11} \mathrm{MKTCAP}_{\mathrm{t}-1}+\alpha_{21} \mathrm{CEX}_{\mathrm{t}-1}+\alpha_{31} \mathrm{REX}_{\mathrm{t}-1+}+\alpha_{41} \mathrm{NOR}_{\mathrm{t}-1}+\alpha_{51} \mathrm{DBT}_{\mathrm{t}-1}+\mathrm{U}_{\mathrm{t} 1} \\
\text { CEX }_{\mathrm{t}}=\beta_{02}+\beta_{12} \mathrm{MKTCAP}_{\mathrm{t}-1}+\beta_{22} \mathrm{CEX}_{\mathrm{t}-1}+\beta_{32} \mathrm{REX}_{\mathrm{t}-1}+\beta_{42} \mathrm{NOR}_{\mathrm{t}-1}+\beta_{52} \mathrm{DBT}_{\mathrm{t}-1+\mathrm{U}_{\mathrm{t} 2}} \\
\operatorname{REX}_{\mathrm{t}}=\gamma_{03}+\gamma_{13} \mathrm{MKTCAP}_{\mathrm{t}-1}+\gamma_{23} \mathrm{CEX}_{\mathrm{t}-1}+\gamma_{33} \mathrm{REX}_{\mathrm{t}-}+\gamma_{43} \mathrm{NOR}_{\mathrm{t}-1}+\gamma_{53} \mathrm{DBT}_{\mathrm{t}-1}+\mathrm{U}_{\mathrm{t} 3} \\
\mathrm{NOR}_{\mathrm{t}}=\mathrm{Z}_{04}+\mathrm{Z}_{14} \mathrm{MKTCAP}_{\mathrm{t}-1}+\mathrm{Z}_{24} \mathrm{CEX}_{\mathrm{t}-1}+\mathrm{Z}_{34} \mathrm{REX}_{\mathrm{t}-1}+\mathrm{Z}_{44} \mathrm{NOR}_{\mathrm{t}-1}+\mathrm{Z}_{54} \mathrm{DBT}_{\mathrm{t}-1}+\mathrm{U}_{\mathrm{t} 4} \\
\mathrm{DBT}_{\mathrm{t}}=\partial_{05}+\partial_{15} \mathrm{MKTCAP}_{\mathrm{t}-1}+\partial_{25} \mathrm{CEX}_{\mathrm{t}-1}+\partial_{35} \mathrm{REX}_{\mathrm{t}-1}+\partial_{45} \mathrm{NOR}_{\mathrm{t}-1}+\partial_{55} \mathrm{DBT}_{\mathrm{t}-1}+\mathrm{U}_{\mathrm{t} 5}
\end{gathered}
$$

The Operational form (Apriori Expectation)

$\alpha_{1}, \alpha_{2}, \alpha_{3}$ and $\alpha_{4}>0<0$, are coefficient of CEX, REX, NOR and DBT. It is expected that fiscal policy variables either positively or negatively relate with capital market performance

\section{Trend and Description of Data}

\subsection{Trend Analysis}

Let's examine the data features of sources for the analysis. Figure 1 below shows upward movement with periods peaks and troughs suggesting mild fluctuations in the distribution of data, except DBT that has smooth upward movement with gradual inclination from 1990 to 2005 , then rapid growth from 2006 to 2018 .

\subsection{Descriptive Statistics}

Table 1 below depicts the summary of statistics that describe the distributional characteristics of all the data. The variables recorded mean or average sums of the following in Billion Naira; 6394.831, 538.1970, 1627.796, 1192.854 and 3254.482 for MKTCAP, CEX, REX, NOR and DBT respectively. DBT only showed Kurtosis greater than 3, indicating a leptokurtic distribution, while MKTCAP, CEX, REX and NOR kurtosis are lower than 3 showing platykurtic distributions. Judging with skewness none is mesokurtic or symmetric or normal distribution. The skewness coefficients are 0.777494, 0.674997, 0.805062, 0.794422 and 1.275816 for MKTCAP, CEX, REX, NOR and DBT respectively, indicating all have positive stewed

\begin{tabular}{|c|c|c|c|c|c|}
\hline & MKTCAP & CEX & REX & NOR & DBT \\
\hline Mean & 6394.831 & 538.1970 & 1627.796 & 1192.854 & 3254.482 \\
\hline Median & 1735.900 & 468.3620 & 1008.500 & 621.6175 & 1350.003 \\
\hline Maximum & 21904.04 & 1682.099 & 5675.186 & 4006.000 & 12774.40 \\
\hline Minimum & 12.80000 & 15.03410 & 25.99420 & 14.73990 & 47.04960 \\
\hline Std. Dev. & 7609.942 & 433.0433 & 1688.819 & 1267.325 & 3926.891 \\
\hline Skewness & 0.777494 & 0.674997 & 0.805062 & 0.794422 & 1.275816 \\
\hline Kurtosis & 2.060554 & 2.783245 & 2.381445 & 2.181198 & 3.338424 \\
\hline Probability & 0.127093 & 0.310859 & 0.155759 & 0.135771 & 0.015909 \\
\hline Sum & 191844.9 & 16145.91 & 48833.88 & 35785.63 & 97634.47 \\
\hline Sum Sq. Dev. & $1.68 \mathrm{E}+09$ & 5438269. & 82711146 & 46577262 & $4.47 \mathrm{E}+08$ \\
\hline Observations & 30 & 30 & 30 & 30 & 30 \\
\hline
\end{tabular}
distribution. Jarque-Bera normality distribution test statistic recorded probability values of $0.127093,0.310859,0.155759$ and 0.135771 for MKTCAP, CEX, REX and NOR variables respectively, showing evidence of normal distribution while DBT has 0.015909 suggesting abnormal distribution.

Table 1. Descriptive Statistics MKTCAP, CEX, REX, NOR and DBT. 

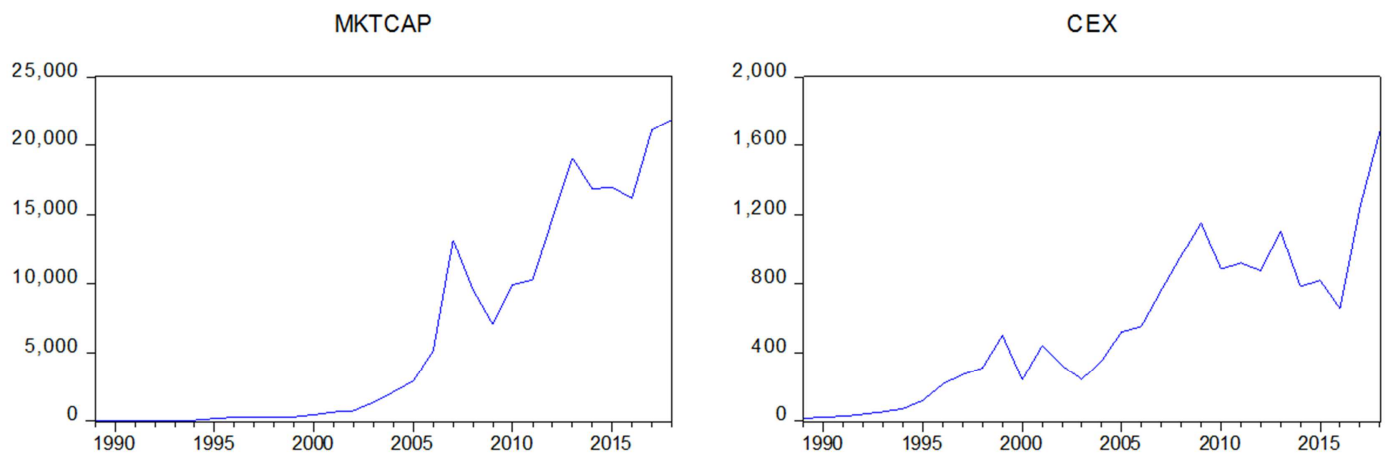

REX
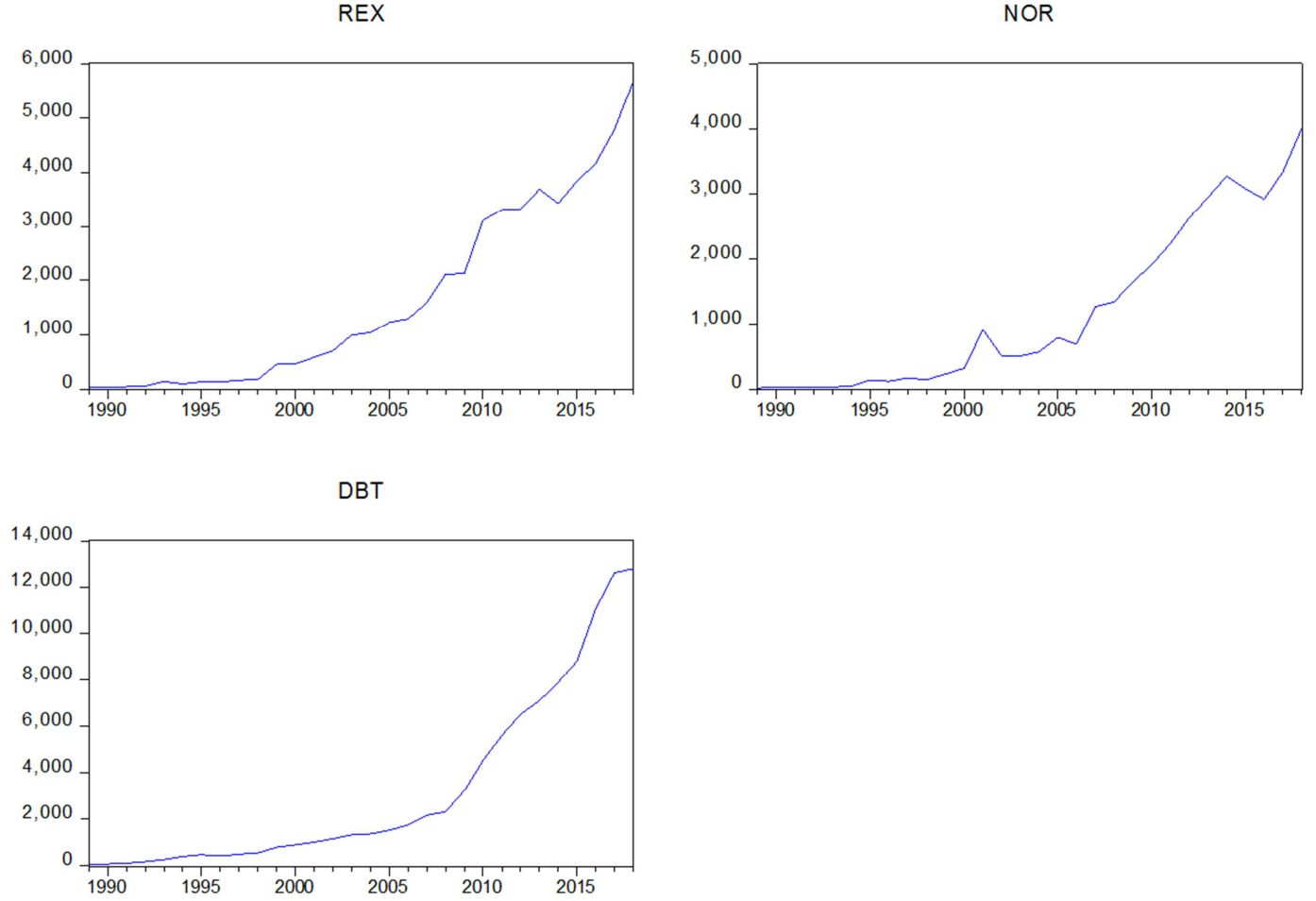

Figure 1. Trend of the time series of MKTCAP, CEX, REX, NOR and DBT.

\section{Results}

\subsection{Level Series Multiple Regression}

The researchers engaged regression analysis to check the relationship between fiscal policy and capital market performance shown below;
Table 3 depicts Level Series Multiple Regression estimated model for the relationship between fiscal policy and performance of capital market. From the table DurbinWatson statistics is 0.845564 , showing presence of autocorrelation. This is unreliable and calls for further examination.

Table 2. Level Series Multiple Regression for MKTCAP, CEX, REX, NOR and DBT.

\begin{tabular}{llll}
\hline Dependent Variable: LNMKTCAP & & & \\
\hline Method: Least Squares & & & St-Statistic \\
\hline Variable & Coefficient & Std. Error & Prob. \\
\hline LNCEX & 0.178148 & 0.205373 & 0.867433 \\
LNREX & 0.672899 & 0.300062 & 2.242536 \\
LNNOR & 0.506176 & 0.280456 & 1.804831 \\
LNDBT & 0.122120 & 0.255994 & 0.477045 \\
C & -2.233143 & 0.617250 & -3.617893 \\
R-squared & 0.974385 & Mean dependent var & 0.0340 \\
Adjusted R-squared & 0.970286 & S. D. dependent var & 0.6375 \\
F-statistic & 237.7451 & Durbin-Watson stat & \\
Prob (F-statistic) & 0.000000 & & 0.0013 \\
\hline
\end{tabular}




\subsection{Stationarity/Unit Root Test}

This is statistical tested and approved procedure in macroeconomics time series analysis that assists to determining the best estimation method for a model. This is because of the peculiarities of time series data. To do this the popular Augmented Dickey Fuller (ADF) unit root/stationary test is employed as shown below.

Table 4 shows the summary of stationary test. The results indicates that all the variables; MKTCAP, CEX, REX, NOR and DBT are integrated at order. Suitable for ECM and VAR estimations.

Table 3. Augmented Dickey Fuller Unit Root Test.

\begin{tabular}{|c|c|c|c|c|c|}
\hline \multirow{2}{*}{ Variables } & \multirow[t]{2}{*}{ Lag SCI } & \multicolumn{2}{|l|}{ ADF Statistic } & \multirow{2}{*}{$\begin{array}{l}\text { CRITICAL VALUES } \\
10 \%\end{array}$} & \multirow{2}{*}{$\begin{array}{l}\text { Remarks } \\
\text { Stationarity }\end{array}$} \\
\hline & & With Prob. Value & $5 \%$ & & \\
\hline LnMKTCAP & 7 & $-4.069552(0.0040)$ & -2.971853 & -2.625121 & @1 (1) \\
\hline LnCEX & 7 & $-6.093663(0.0000)$ & -2.971853 & -2.625121 & @1 (1) \\
\hline LnREX & 7 & $-7.579425(0.0000)$ & -2.971853 & -2.625121 & @1 (1) \\
\hline LnNOR & 7 & $-7.471144(0.0000)$ & -2.971853 & -2.625121 & @1 1) \\
\hline LnDBTS & 7 & $-3.804203(0.0076)$ & -2.971853 & -2.625121 & (a)1 (1) \\
\hline
\end{tabular}

\subsection{Cointegration and Long Run Relationship Test}

This is necessary to know if there exist equilibrium relationships between the variables; capital market performance indicator (MKTCAP) and fiscal policy variables (CEX, REX, NOR and DBT) as shown below;

Table 5 below shows that unrestricted rank tests (Trace and
Maximum Eigenvalue) recorded four cointegration equations at $5 \%$ level of significant at none, at most 1 , at most 2 , and at most 4 respectively. This is sufficient evidence to show that long run relationship exists between the dependent variable capital market performance proxied by MKTCAP and independent variables; fiscal policy variables (CEX, REX, NOR and DBT).

Table 4. Johansen Cointegration Test.

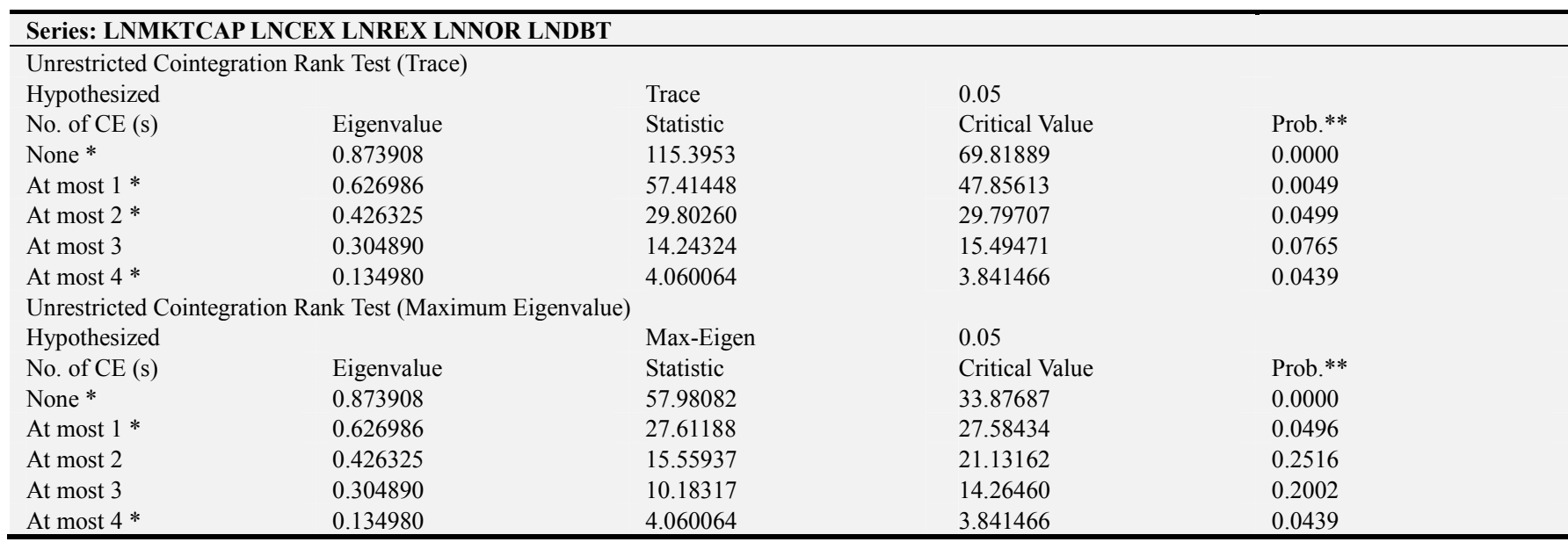

\subsection{Causal Relationship Between MKTCAP, CEX, REX, NOR and DBT}

In macroeconomic analysis, causality test is common tool used in to check if causality exists or otherwise, between any two variables;

From the table 5 below, REX granger cause MKTCAP as such causally prior to MKTCAP (F-stat ReX $=15.8258$; Prob $_{\mathrm{REX}}=$ 0.00005 , significant at $5 \%$ ). In the same way, NOR granger cause MKTCAP $\left(\mathrm{F}_{-\mathrm{stat}_{\mathrm{NOR}}}=3.24426 ; \quad \operatorname{Prob}_{\mathrm{NOR}}=0.0574\right.$, significant at $10 \%$ ). That shows unidirectional causality between REX, NOR and MKTCAP. While, DBT granger cause MKTCAP $\left(\mathrm{F}_{- \text {stat }_{\mathrm{DBT}}}=4.34745\right.$; Prob $_{\mathrm{DBT}}=0.0250$, significant at $5 \%$ ), also MKTCAP granger cause DBT (F-stat ${ }_{\mathrm{MKTCAP}}=11.5038$; Prob $_{\mathrm{MKTCAP}}=0.0003$, significant at $5 \%$ ), indicating bidirectional causality. That shows DBT and MKTCAP drive each other. CEX has no identifiable causality with MKTCAP since their pvalues are greater than the significant levels of $5 \%$ and $10 \%$.

Table 5. Pairwise Granger Causality Test Results.

\begin{tabular}{llll}
\hline Null Hypothesis: & Obs & F-Statistic & Prob. \\
\hline CEX does not Granger Cause MKTCAP & 28 & 0.96436 & 0.3961 \\
MKTCAP does not Granger Cause CEX & & 2.30758 & 0.1221 \\
REX does not Granger Cause MKTCAP & 28 & 15.8258 & 5. E-05 \\
MKTCAP does not Granger Cause REX & & 0.07354 & 0.9293 \\
NOR does not Granger Cause MKTCAP & 28 & 3.24426 & 0.0574 \\
\hline
\end{tabular}




\begin{tabular}{lcll}
\hline Null Hypothesis: & Obs & F-Statistic & Prob. \\
\hline MKTCAP does not Granger Cause NOR & & 1.68564 & 0.2074 \\
DBT does not Granger Cause MKTCAP & 28 & 4.34745 & 0.0250 \\
MKTCAP does not Granger Cause DBT & & 11.5038 & 0.0003 \\
\hline
\end{tabular}

\subsection{Contemporaneous Relationship Between MKTCAP, CEX, REX, NOR and DBT}

This is useful to determine the relationship between performance of capital market and fiscal policy variables. It can be recalled that Level Series Multiple Regression exhibits unsatisfactory result, and was therefore abandoned. Therefore, the researchers therefore adopt Error Correction Model (ECM) to further examine the long run relationship between performance of capital market and fiscal policy variables, and also capture the short run deviations of the parameters from the long run equilibrium by incorporating lagged residuals.

Table 6 below shows that the output of the ECM. MKTCAP at lag 1 has coefficient of 0.631240 and p-value of 0.0089 , which is significant at 5\% level, suggesting MKTCAP is autoregressive, hence reinforces itself. REX at lag 1 has coefficient of -0.657713 with p-value of 0.0296 , significant at 5\% level and NOR at lag 1 has coefficient of -
0.355826 associated with p-value of 0.0961 , significant at $10 \%$, while, DBT at lag1 has 1.234086 coefficient at $10 \%$ significance level. The results show that REX and NOR have negative and significant relationship with MKTCAP, whereas DBT has positive and significant relationship with MKTCAP. It is also found that CEX has no significant relationship with MKTCAP. The Durbin-Watson statistics is 2.178249, showing no presence of autocorrelation in the model estimated, which shows no presence of autocorrelation, suggesting the model is suitable to adduce the Contemporaneous Relationship between capital market performance (MKTCAP) and fiscal policy variables (CEX, REX, NOR and DBT). The ECM has coefficient of 0.582563 and p-value of 0.0107 which is statistically significant, the model is correctly signed. From the coefficient the speed of adjustment of the model due to short run deviations or shock is $58.8 \%$ annually. In all fiscal policy have significant impact on the performance of the capital market in Nigeria.

Table 6. Error Correction Model (ECM).

\begin{tabular}{|c|c|c|c|c|}
\hline \multicolumn{5}{|c|}{ Dependent Variable: D (LNMKTCAP) } \\
\hline \multicolumn{5}{|c|}{ Method: Least Squares } \\
\hline Variable & Coefficient & Std. Error & t-Statistic & Prob. \\
\hline D(LNMKTCAP(-1)) & 0.631240 & 0.211916 & 2.978730 & 0.0089 \\
\hline $\mathrm{D}(\mathrm{LNCEX}(-1))$ & 0.207313 & 0.201563 & 1.028528 & 0.3190 \\
\hline $\mathrm{D}(\operatorname{LNCEX}(-2))$ & 0.329857 & 0.232716 & 1.417425 & 0.1755 \\
\hline D(LNREX(-1)) & -0.657713 & 0.275299 & -2.389083 & 0.0296 \\
\hline D(LNNOR(-1)) & -0.355826 & 0.201233 & -1.768227 & 0.0961 \\
\hline D(LNNOR(-2)) & -0.156874 & 0.227897 & -0.688353 & 0.5011 \\
\hline D(LNDBT(-1)) & 1.234086 & 0.594886 & 2.074491 & 0.0545 \\
\hline D(LNDBT(-2)) & -0.284565 & 0.552364 & -0.515176 & 0.6135 \\
\hline $\operatorname{ECM}(-1)$ & -0.582563 & 0.201579 & -2.890002 & 0.0107 \\
\hline R-squared & 0.588884 & \multirow{3}{*}{\multicolumn{2}{|c|}{$\begin{array}{l}\text { Mean dependent var } \\
\text { S. D. dependent var }\end{array}$}} & 0.253874 \\
\hline Adjusted R-squared & 0.331936 & & & 0.320045 \\
\hline Durbin-Watson stat & 2.178249 & & & \\
\hline
\end{tabular}

\subsection{Unrestricted VAR Analysis}

\subsubsection{VAR Lag Length Selection}

As statistically established, the first step in estimating the VAR model is to determine the lag length for a parsimonious specification. To achieve this, the researchers engaged all the automatic lag selection criteria as shown below;

The VAR lag order selection criteria on table 7 reveals that lag length of 2 is selected at $5 \%$ level based on sequential modified LR test statistic, Final prediction error (FPE), Akaike information criterion (AIC), and Hannan-Quinn information criterion (HQ), suggesting that VAR (2) specification is the parsimonious model and the plausible description of the data used. The researchers boldly proceed to estimate a VAR (2) model for check how capital market responds to its own shock and shocks from fiscal policy variables. Before that, it is necessary to do a diagnostic test to know the validity of subsequent results.

Table 7. VAR Lag Order Selection Criteria.

\begin{tabular}{|c|c|c|c|c|c|c|}
\hline \multicolumn{7}{|c|}{ VAR Lag Order Selection Criteria } \\
\hline \multicolumn{7}{|c|}{ Endogenous variables: LNMKTCAP LNCEX LNREX LNNOR LNDBT } \\
\hline Lag & $\log \mathbf{L}$ & LR & FPE & AIC & SC & HQ \\
\hline 0 & -87.44646 & NA & 0.000508 & 6.603318 & 6.841212 & 6.676045 \\
\hline 1 & 33.08681 & 189.4094 & $5.71 \mathrm{e}-07$ & -0.220486 & 1.206876 & 0.215872 \\
\hline 2 & 80.98982 & 58.16794* & $1.34 \mathrm{e}-07 *$ & $-1.856416^{*}$ & $0.760415^{*}$ & $-1.056425^{*}$ \\
\hline
\end{tabular}




\subsubsection{Residual Diagnostic Test}

This is to know the reliability of the results that will come out from the estimation using VAR Residual Serial Correlation LM and VAR Residual Heteroscedasticity.

In Table 8 below, VAR Residual Serial Correlation LM Tests has at lag 1 and 2 P-values of 0.5666 and 0.5713 , which an indication of rejection of the null hypothesis, showing evidence no serial correlation.

Table 8. VAR Residual Serial Correlation LM Tests.

\begin{tabular}{lllllll}
\hline \multicolumn{6}{l}{ VAR Residual Serial Correlation LM Tests } \\
\hline Lag & LRE* stat & Df & Prob. & Rao F-stat & Df & Prob. \\
\hline 1 & 23.83007 & 25 & 0.5292 & 0.932680 & $(25,31.2)$ & 0.5666 \\
2 & 23.74607 & 25 & 0.5341 & 0.928394 & $(25,31.2)$ & 0.5713 \\
\hline
\end{tabular}

Table 9 below shows that Chi-sq is 309.3149 with P-value of 0.3433 . This is sufficient evidence suggesting of homoscedasticity the model.

Table 9. VAR Residual Heteroscedasticity Test.

\begin{tabular}{lll}
\hline \multicolumn{3}{l}{ VAR Residual Heteroskedasticity Tests (Levels and Squares) } \\
\hline Joint test: & & \\
\hline Chi-sq & Df & Prob. \\
309.3149 & 300 & 0.3433 \\
\hline
\end{tabular}

\subsubsection{Stability Check}

To examine the stability of the estimated VAR (2) model, the researchers used Inverse roots of Autoregressive Characteristic Polynomial and Normality by ploting the inverted roots in relation to unit circle. It is statistically known that the estimated VAR model is stable if all the inverted points are inside the unit circle as shown below;

Figure 2 below shows the inverse roots of the characteristics AR polynomial. It indicates that all roots fall or lie within the unit imaginery circle (modulus), an indication that VAR (2) model is stable.

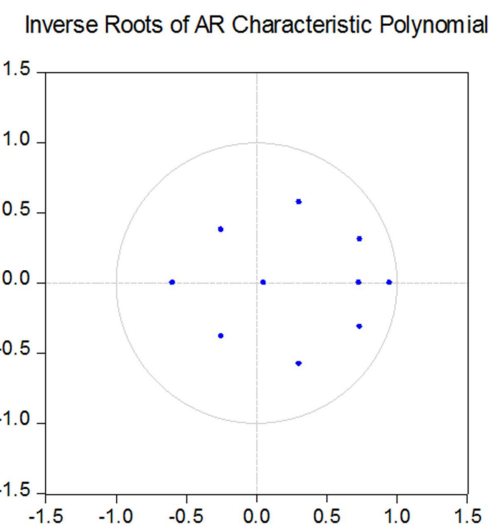

Figure 2. Graphical Representation of Inverse roots of AR Characteristic Polynomial.

\subsubsection{Error Correction and Long Run Causality Test}

Having established that the variables are cointegrated, there is likelihood of adjustment from short run to long run equilibrium. That is to say that errors encountered in the short run can be corrected or adjusted in the long run. To achieve the consistency, the researchers estimated the model with Vector Error Correction Estimates as shown below;

Table 10 blew reveals that error correction equation (CointEq1) has coefficient of -0.555338 and t-statistic of 2.01669 , suggesting that means error correction parameter is negative and significant, satisfying the apriori expectation. The speed of adjustment is $55.5 \%$. The cointegration already established is confirmed. That means short term errors can be corrected in the long run with annual speed of adjustment $55.5 \% \%$. It also confirms that long run causality flows from fiscal policy instruments (CEX, REX, NOR and DBT) to capital market performance (MKTCAP).

Table 10. Vector Error Correction Estimates.

\begin{tabular}{llllll}
\hline Vector Error Correction Estimates & & & & \\
\hline Error Correction: & D (LNMKTCAP) & D (LNCEX) & D (LNREX) & D (LNNOR) & D (LNDBT) \\
\hline CointEq1 & -0.555338 & 0.361627 & -0.009161 & 0.200110 & 0.252007 \\
& $(0.27537)$ & $(0.25660)$ & $(0.28830)$ & $(0.16414)$ & $(0.07608)$ \\
& {$[-2.01669]$} & {$[1.40931]$} & {$[-0.03178]$} & {$[1.21912]$} & {$[3.31251]$} \\
\hline
\end{tabular}

\subsubsection{Short run Causality Test}

To examine the short run causality implications of the variables, the researchers adopted VEC Granger Causality/Block Exogeneity Wald Test as depicted below;

Table 11 below shows that Chi-square statistic coefficient of 'All' is 19.29387 with p-value of 0.0134 , suggesting that all the fiscal policy variables (CEX, REX, NOR and DBT) jointly cause capital market performance (MKTCAP) in the long run. Separately, REX Chi-square statistic coefficient of 12.41648 with p-value of 0.0020 , which is significant at $5 \%$, suggesting MKTCAP cause REX in both in the short run and long run. While, CEX, NOR and DEBT have p-values of $0.3160,0.2599$ and 0.5835 respectively, indicating that they are not significant, indicating CEX, NOR and DEBT do not cause MKTCAP in the short run but in the long run.

Table 11. VEC Granger Causality/Block Exogeneity Wald Test.

\begin{tabular}{llll}
\hline \multicolumn{5}{l}{ VAR Granger Causality/Block Exogeneity Wald Tests } \\
\hline Dependent variable: LNMKTCAP & (f & Prob. \\
\hline Excluded & Chi-sq & df & 0.3160 \\
\hline LNCEX & 2.304301 & 2 & 0.0020 \\
LNREX & 12.41648 & 2 & 0.2599 \\
LNNOR & 2.695029 & 2 & 0.5835 \\
LNDBT & 1.077407 & 2 & 0.0134 \\
All & 19.29387 & 8 &
\end{tabular}

\subsubsection{Impulse Response of ROA to Its Own Shock and} Shocks from MKTCAP, CEX, REX, NOR and DBT

As seen from the previous analysis, all the fiscal policy variables (CEX, REX, NOR and DBT) contemporaneously 
and inter-temporally do not jointly cause or relate to capital market performance (MKTCAP), hence need to examine the shocks or innovations of MKTCAP from itself and from CEX, REX, NOR and DBT. Again, examine the dynamic impacts or shocks of fiscal policy variations on capital market performance. This is achieved with impulse responses and variance decomposition as depicted below;

From figure 3 , the impulse response function shows one time shock to the variables. It shows that MKTCAP responds gradually on positive side to own shock from first year until the tenth year. While MKTCAP responds to shocks of CEX and REX positively from the first year to tenth year, but MKTCAP responds to the shock of DBT slightly and positively from the first year to eightieth year, then fades away, whereas MKTCAP responds to the shock from NOR negatively from the first to tenth year.

Response to Cholesky One S.D. (d.f. adjusted) Innovations \pm 2 S.E.

Response of LNMKTCAP to LNMKTCAP
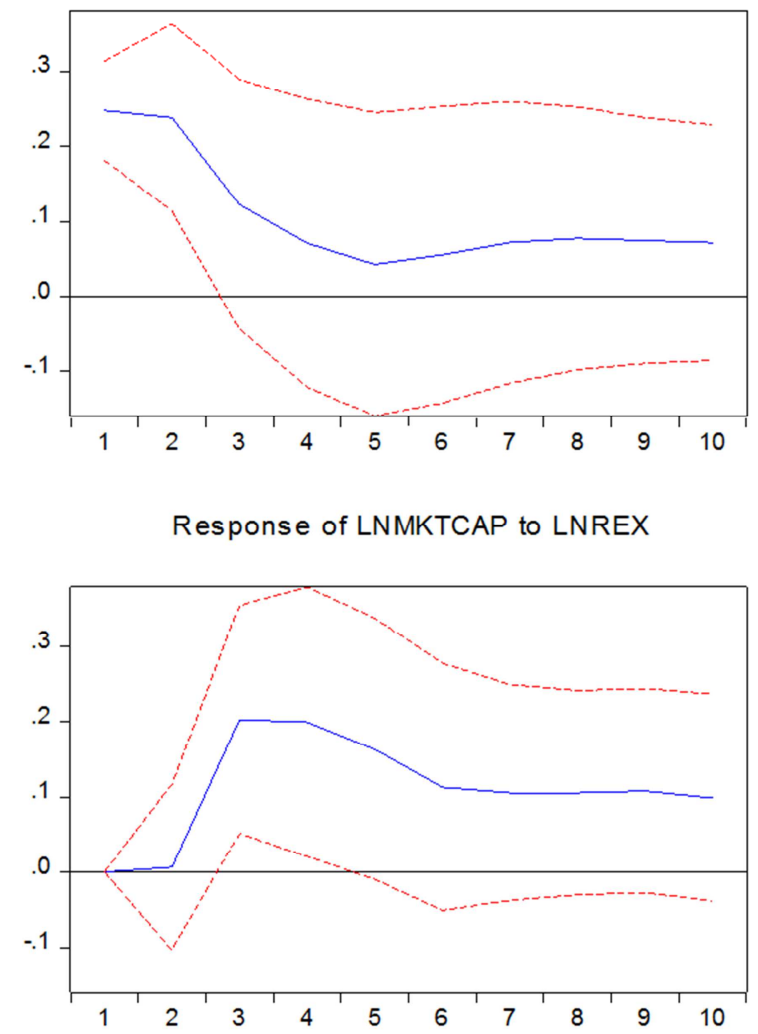

Response of LNMKTCAP to LNDBT

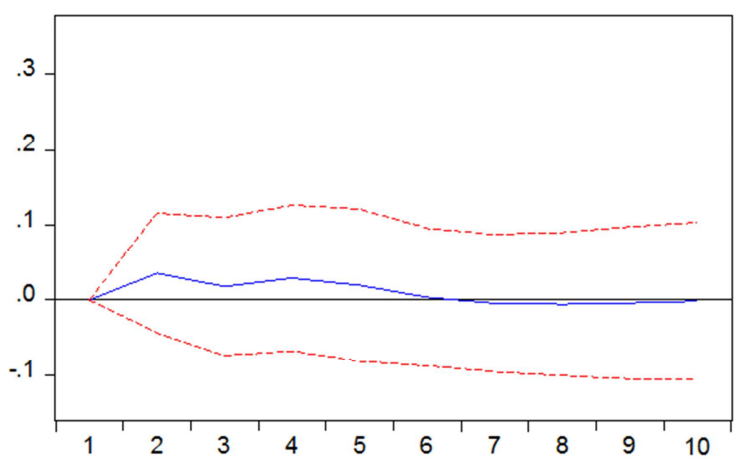

Response of LNMKTCAP to LNCEX
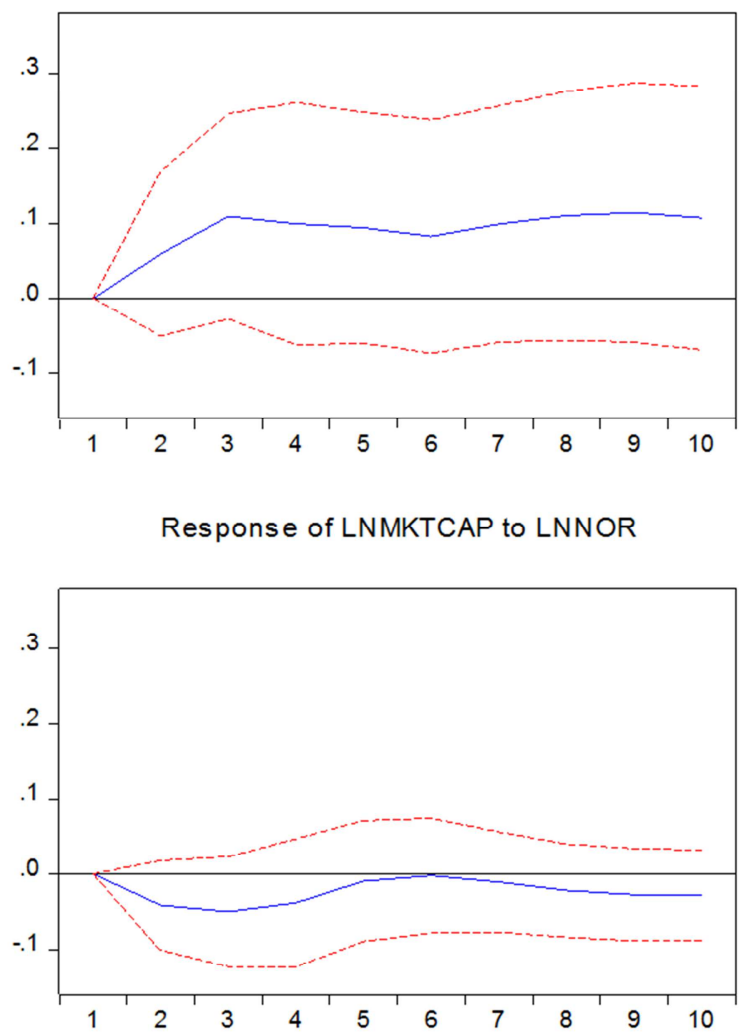

Figure 3. Graph depicting Responses of MKTCAP to Shocks.

\subsubsection{Variance Decomposition of MKTCAP CEX, REX, NOR and DBT}

From figure 4, MKTCAP own shock caused 100 percent variations in the first period and diminished gradually to $39.5 \%$. That shows that own shock exerted huge influence in the cause of variation on capital performance followed by CEX and REX that started from $0 \%$ in the first year and rose slightly to $20 \%$ and greatly to $39.2 \%$ respectively in the tenth year. The shocks of NOR and DBT are insignificant. 
Variance Decomposition using Cholesky (d.f. adjusted) Factors

Percent LNMKTCAP variance due to LNMKTCAP

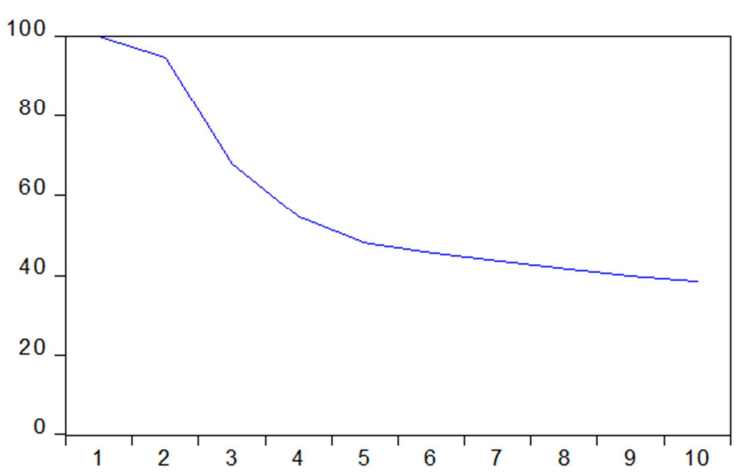

Percent LNMKTCAP variance due to LNREX

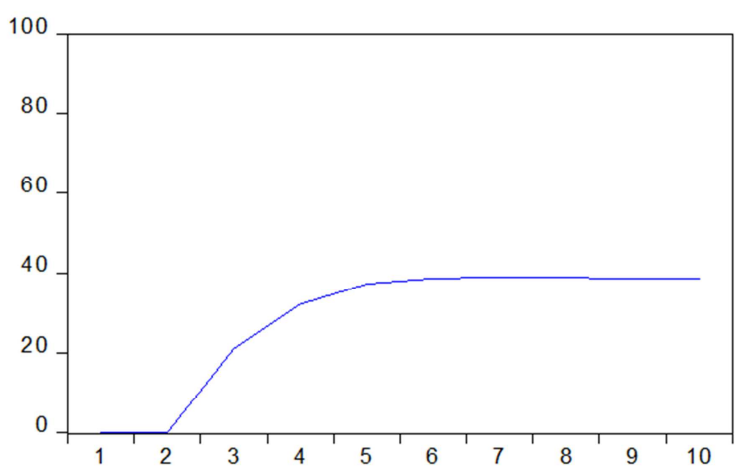

Percent LNMKTCAP variance due to LNDBT

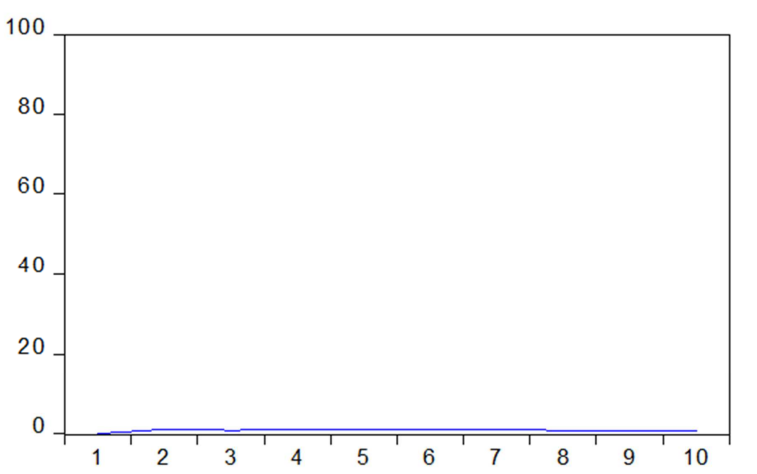

Percent LNMKTCAP variance due to LNCEX

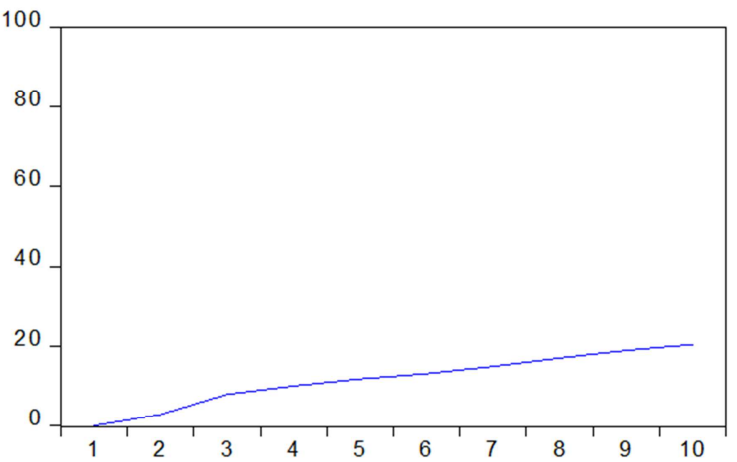

Percent LNMKTCAP variance due to LNNOR

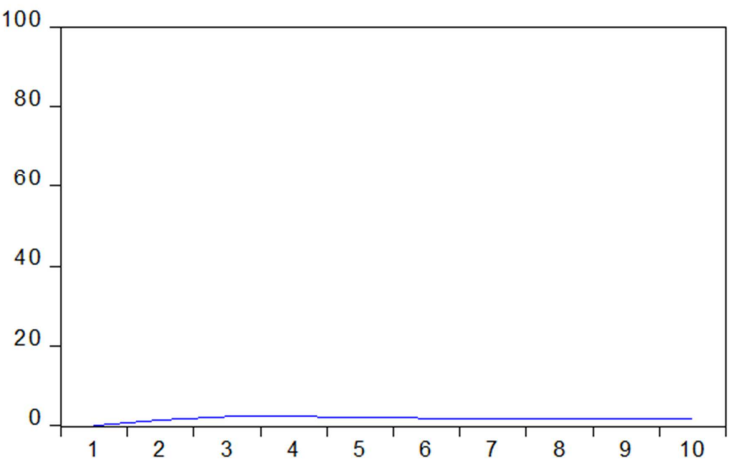

Figure 4. Variance Decomposition Results.

\section{Conclusions and Recommendations}

This study has validated the assertions of many economic and finance scholars that fiscal policy tools are veritable measures to steer the stability of the financial system which habours the capital market as a major component. The researchers' position in this study was based on the following major findings; Market Capitalization as a performance index in this study is autoregressive, implying that previous market capitalization can predict investors' perception of the market in the future. The results show that recurrent expenditure and Non-Oil Revenue have negative and significant relationship with capital market performance in Nigeria. Domestic debt was also found to have a positive and significant relationship with capital market performance, validating the Keynes's postulations reviewed in this study that government should adopt fiscal policy through deficit financing to put an end of further economic depression and related issues [25]. This is also confirmed with the causality that indicated bi-directional effect between domestic debt and market capitalization, implying that the duo drive each other or have feedback effect. The impulse responses revealed that market capitalization shock (own shock) exerted huge influence in the cause of variation on capital market performance 
followed by shocks from government expenditures. It was also found that fiscal policy variables jointly cause capital market performance in the long run.

Consequent upon the findings, the researchers advise the regulatory authorities in Nigeria that government revenues and expenditure be adequately orchestrated as main drivers to correct disequilibria in the Nigerian financial system. Again, despite this study found a positive and significant relationship between domestic debt and capital market performance, public policy and board room policy makers should be aware that fiscal policy through deficit financing can induce an increase in interest rates with a corresponding reduction in the funds invested, thereby slowing growth in the capital market.

\section{References}

[1] Afonso, A. \& Sousa R. M., (2009). Fiscal policy, housing and stock prices. European Central Bank, Working paper, 990.

[2] Afonso, A. \& Sousa, R. M., (2011). What are the effects of fiscal policy on asset markets? European Central Bank, Working paper, 28, 1871-1890.

[3] Afonso, A. \&Sousa, R. M. (2012). The macroeconomic effects of fiscal policy. Applied Economics, 44, 4439-4454.

[4] Agnello L., Dufrénot G. \& Sousa R. M., (2015). Nonlinear effects of asset prices on fiscal policy: Evidence from the UK, Italy and Spain. Journal Elsevier, Economic Modeling, 44, 358-362

[5] Anghelache, G., Jakova, S \& Oanea, D. (2016). Fiscal policy and capital market performance: Evidence from European Union countries from Central and Eastern Europe. International Journal of Academic Research in Accounting, Finance and Management Sciences, 6 (2), 34-63.

[6] Ardagna S., (2009). Financial markets. behavior around episodes of large changes in the fiscal stance. European Economic Review, 53, 37-55.

[7] Ardagna, S., Caselli, F. \& Lane, T. (2004). Fiscal discipline and the cost pf public debt service: some estimates for OECD countries. HU Working Paper, Cambridge: Harvard University

[8] Babalola, J. A. \& Adegbite, M. A. (2001) The performance of the Nigerian capital market since deregulation in 1986. Central Bank of Nigeria Economic and Financial Review, 39 (1), 1-20.

[9] Balassone, F., Franco, D. \& Giordano, R. (2004). Market induced fiscal discipline: is there a fallback solution for rulefailure? BI Working Paper, Perugia: Banca d Italia.

[10] Barro, R. J. (1974). Are government bonds net wealth? Journal of Political Economy, 82, 1095-1117.

[11] Barro, R. J., (1979). On the determination of public debt. Journal of Political Economy. 87, 940-971.

[12] Bhalla, V. K. (2011). Investment management: Security analysis and portfolio management. New Delhi: S. Chad and Company Ltd.
[13] Blanchard, O. J. (1981) Output, the stock market and interest rates. American Economic Review, 71, 132-43.

[14] Brealey, R. A. \& Myers, S. C. (2003). Principles of corporate finance. New Delhi: McGraw Hill.

[15] Eyo, E. (2016). Impact of fiscal policy on the performance of the Nigerian stock exchange. International Journal of Interdisciplinary Social Science Studies, 2 (1), 36-44

[16] Ezirim, C. B., Muohgalu, M. I., Elike, U. \& Amuzie, A. E. (2010). Public expenditure growth, inflation and cointegration evidence from Nigeria. International Journal of Business and Behavioural Sciences Research, 1 (1), 1-14.

[17] Fama, E. F. (1970). Efficient capital markets: A review of theory and empirical work. Journal of Finance, 25 (1), 83-417.

[18] Fisher, D. E. \& Jordan, R. J.(2005). Security analysis and portfolio management. Delhi: Pearson Education.

[19] Göndör, M. \& Bresfelean, V. P. (2011). Fiscal policy, the main tool to influence the capital markets' strength. Conference on Recent Advances in Applied \& Biomedical Informatics and Computational Engineering in Systems Applications, 458-463. https://www.researchgate.net/publication/262233178 Fiscal policy_the_main_tool_to_influence_the_capital_markets\%27 strength.

[20] Hsing, Y. (2013) Effects of fiscal policy and monetary policy on the stock market in Poland. Economies, 1, 19-25. Available from: http://dx.doi.org/10.3390/economies.

[21] https://www.imf.org/external/pubs/ ft/staffp/2003/00-00/rv.pdf. Retrieved 30/3/2020.

[22] Ibenta, S. N. (2005). Investment analysis and financial management strategy. Enugu: Institute of Development Studies.

[23] Karlygash, K. (2013). Optimal fiscal policy and different degrees of access to international capital market. Journal of Development Economics, 103.

[24] Kendall, M. G. (1953). The analysis of economic time series, Prices. Journal of the Royal Statistical Society, 96, 11-25.

[25] Keynes, J. M. (1936). The general theory of employment, interest and money. Reviewed by: F. Vito Rivista. Internationale di Scienze Sociali Serie III, 7 (44), 654-656.

[26] Laopodis, N. (2010). Dynamic linkages between monetary policy and the stock market. Review of Quantitative Finance and Accounting, 35, 271-293.

[27] Monacelli, T. \& Perotti, R. (2006). Fiscal policy, the trade balance, and the real exchange rate: implications for international risk sharing. IGIER, Working Paper, Milan: Bocconi University.

[28] Ogbulu, O. M., Torbira, L. L. \& Umezinwa, C. L. (2015). Assessment of the impact of fiscal policy operations on stock price performance: Empirical evidence from Nigeria. International Journal of Financial Research, 2 (6), 190-202.

[29] Okafor, F. O. (1983). Investment decisions: Evaluation of projects and securities. London: Cassel.

[30] Perotti, R. (2005). Estimating the effects of fiscal policy in OECD countries. CEPR Discussion Paper, 168, Milan: Bocconi University 
[31] Razin, A. (1987). Fiscal policies and the stock markets: International dimensions. National Bureau of Economic Research: Working Paper Series, No. 2389.

[32] Riascos A. \& Vegh C., (2003). Pro-cyclical government spending in developing countries: Therole of capital market imperfections. Banco de la Republica UCLA and NBER, from https://www.imf.org/ external/pubs/ft/staffp/2003/00-00/rv.pdf 25. Retrieved 30/3/2020

[33] Romer, C. \& Romer, D. (2007). The Macroeconomic effects of tax changes: estimates based on a new measure of fiscal shocks. NBER Working Paper, 13264, Cambridge: The National Bureau of Economic Research.
[34] Ross, S. A., Westerfield, R. W., Jaffe, J. \& Jordan, B. D. (2009). Modern financial management ( $8^{\text {th }}$ edition). New Delhi: McGraw Hill.

[35] Shah, A. (1984) Crowding out, capital accumulation, the stock market, and money-financed fiscal policy. Journal of Money, Credit, and Banking, 16, 461-473.

[36] Tavares. J. \& Valkanov, R. (2003). The neglected effect of fiscal policy on stock and bond returns. Social Science Research Network, Electronic Journal. 